\title{
Determination and workout of morphological characteristics of Makhamalabad mini watershed in Nashik district of Maharashtra
}

\author{
ASHWINI P. TIWANE, MAHESH M. KADAM AND P.T.SHINDE
}

Received : 03.12.2016; Revised : 17.03.2017; Accepted : 24.03.2017

See end of the Paper for authors' affiliation

Correspondence to :

MAHESH M. KADAM

School of Agriculture, Lovely Professional University, PHAGWARA (PUNJAB) INDIA Email : maheshkadam1218@ gmail.com
- ABSTRACT : The study was carried out on the preparation of contour map for Makhamalabad site and to determine the morphological characteristics of Makhamalabad mini watershed. Topographic surveying and planning was done for Makhmalabad farm. The watershed selected for the study is located off Peth road at Makhmalabad village of Nashik district. The area of watershed undertaken to study is 4.2 ha. Survey was carried out with grid spacing of $20 \mathrm{~m}$. Contour interval was taken of $1 \mathrm{~m}$. From the study of watershed characteristics it was seen that the watershed has fan shape with small catchment area of 4.2 ha, with stream order 1 . The drainage density was $0.051 \mathrm{~km}$ per sq $\mathrm{km}$. which was relatively very less. So, runoff from catchment was also less. Time of concentration was $3.44 \mathrm{~min}$. It is seen that the watershed has stream order 1 . There were more streams per unit area. The drainage density was $0.051 \mathrm{~km} / \mathrm{km}^{2}$. Thus, the average length of overland flow was more. The area of watershed was less so also the slope and length of stream. This has resulted in higher time of concentration, which was $3.44 \mathrm{~min}$. The length-width ratio was also higher.

- KEY WORDS : Watershed, Drainage density, Catchment, Time of concentration, Contour interval

- HOW TO CITE THIS PAPER : Tiwane, Ashwini P., Kadam, Mahesh M. and Shinde, P.T. (2017). Determination and workout of morphological characteristics of Makhamalabad mini watershed in Nashik district of Maharashtra. Internat. J. Agric. Engg., 10(1) : 130-132, DOI: 10.15740/HAS/IJAE/10.1/130-132. 